\title{
Educating the seamstress: studying and writing the memory of work
}

Maria Tamboukou

University of East London, UK

Bryn Mawr, August 4th, 1922

My dearest Comrade:

This will be the last letter you will receive from Bryn Mawr. Next week this time, I will be with you again in the dusty city doing my daily work in the shop and spending the evenings with you in the little office, planning to organize the non-organized. Really, dear comrade, when I look back into the past, not very long, oh say only two months ago, I find such a change in my thoughts.... Let me share with you my new discoveries.

To begin with I might proudly say that the pulse of the US beats in Bryn Mawr at this very moment. We have students from each state and of course you will agree with me that each state has its own way of living, with its joys and sorrows; with its customs, traditions etc that reflects on the children of that state ... they use different methods, but they all love the work.... As an example I'll take a state in the south, Tennessee. We have quite a few girls from there. Most of them are timid, have very little knowledge, general knowledge I mean.... Most of them are loyal members of the ' $Y$ ' which has sent them here and is supporting them financially. They know very little of the outside world, but you just tell them in the South the negro is discriminated against, and you will hear them talk! They are born aristocrats and as such they cannot stand criticism of their deeds. The Northern group is rather more progressive. You hear discussions in Unionism, some are even officials in their local unions also members of the A.F. of L. Their minds are open for conviction, more or less some are real hard boiled, but you could get along with them nicely. Most of these girls do not take an active part in the movement outside of their union, but they have heard of the Sacco-Vanzetti case, the famine in Russia, of course through their local unions. The very extreme groups are the radicals, various opinions, various groupings, various methods to attain the freedom of mankind - but they all work for the cause.

The faculty varies also in groups. Some are more progressive, even revolutionary (I am referring to a few girls idealists, who went out to picket the shops the other day; they wanted to be arrested so that it will stir public opinion). Of course since we have this experience, and are having it in our every-day life, I knew that nothing will come out of it, but the thought that these girls are idealistic enough to sacrifice for the welfare of others, does approve of their daring act. They use new methods, others use different methods, but they all love the work, you feel it when you come in close

contact with each one of the faculty. They are not here to 'put things over us', they simply explain us what we do not know and then we ourselves are discussing the question if some of us are wrong, the instructor will always call our attention. Of course we cannot expect that every one gained equal knowledge for this short period. I believe that this school is a start for those who know nothing, and training school for those who do know a little and need a thorough review of what they know. I found out that for these two months I gained a little, imagine I gained with my lazy head, so imagine that the others gained a great deal more.

I hope you will not fall asleep while reading this uninteresting letter. I was and remain a prosaic. 
In August 1922 a young woman was writing a letter to her comrade and colleague in a New York garment shop. The sender was Rose Pesotta, writing from Bryn Mawr College in Pennsylvania, where she had just completed a summer school for women workers. Short as it is, the letter brings together a cluster of themes, ideas and practices that were crucial in the way women garment workers shook and changed the world in the first half of the twentieth century in the US and Europe. Taking Pesotta's epistolary trace of her educational experience at Bryn Mawr as my starting point, in this paper I want to look into a rather grey area in the field of gender and education: women workers' intellectual lives and their dynamic intervention in the socio-historical and cultural formations of the twentieth century.

Narratives, assemblages and the memory of work

Although there have been some important studies in the gendered aspects of workers' education, ${ }^{2}$ my intention in this paper is to excavate women's memory of work through a genealogical approach to narrative analysis. As I have written elsewhere at length, Foucault's genealogical approach scrutinises micro-practices in the constitution of the social and the self and critically interrogates 'truths', discourses and practices around humans and their world. ${ }^{3}$ In continuing with my work of writing

\footnotetext{
${ }^{1}$ Letter from Rose Pesotta, dated August 4, 1922, General Correspondence, Rose Pesotta papers. Manuscripts and Archives Division. The New York Public Library. Astor, Lenox, and Tilden Foundations (RPP/NYPL).

${ }^{2}$ See Rita Heller, 'Blue Collars and Blue Stockings: The Bryn Mawr Summer School for Women Workers, 1921-1938', in Sisterhood and Solidarity: Workers' Education for Women, 1914-1984, ed. J. Kornbluh and M. Frederickson (Philadelphia: Temple University Press, 1984), 107-45; Heller, The Women of Summer, a documentary film, directed by Susan Baumer, 1985; Heller, The Women of Summer: The Bryn Mawr Summer School for Women Workers, 1921-1938 (PhD diss., Rutgers University, 1986); Karyn L. Hollis, Liberating Voices: Writing at the Bryn Mawr Summer School for Women Workers (Carbondale: Southern Illinois University Press, 2004); Kornbluh and Frederickson, Sisterhood and Solidarity; Hilda Worthington Smith, Women Workers at the Bryn Mawr Summer School (New York: Affiliated Summer Schools for Women Workers in Industry and American Association for Adult Education, 1929); Smith, Opening Vistas in Workers' Education: An Autobiography (unknown binding, 1978).

${ }^{3}$ See Maria Tamboukou, Women, Education and the Self, A Foucauldian Perspective. (Basingstoke: Palgrave, 2003) and Tamboukou, In the Fold Between Power and Desire: Women Artists' Narratives (Newcastle: Cambridge Scholars, 2010).
} 
feminist genealogies, I follow Hannah Arendt's conceptualisation of narratives as crucial in making sense of the human condition.

Drawing on the Aristotelian notion of energeia, Arendt's thesis is that 'action as narration and narration as action are the only things that can partake in the most "specifically human" aspects of life'. In acting and speaking together, human beings expose themselves to each other, reveal the uniqueness of 'who' they are and through taking the risk of disclosure they connect with others. In this light narration creates conditions of possibility for uniqueness, plurality and communication to be enacted within the Arendtian configuration of the political. As the only tangible traces of human existence, stories in Arendt's thought evade theoretical abstractions and contribute to the search for meaning by revealing multiple perspectives, while remaining open and attentive to the unexpected, the unthought-of; they 'respect the contingency of action' 5 and express the unpredictability of the human condition. In doing so stories ultimately reconfigure the sphere of politics as an open plane of horizontal connections, wherein freedom can be reimagined.

In this light women workers' narratives constitute 'the grey dusty documents ${ }^{\prime 6}$ of the genealogical method; they re-enact marginalised voices and subjugated knowledges from the archives of the memory of work. As the relevant literature in this field indicates, ${ }^{7}$ it is the minutiae and forgotten details of the world of work that allow glimpses in its past. Women workers' narratives textualise the conditions of their lives and map material and discursive entanglements between workspaces and personal spaces; they foreground the intimate, intense and often invisible ways through which women workers live their workspaces, populate them with ideas, emotions, beliefs and everyday practices, but also imagine them differently.

In looking into women workers' auto/biographical ${ }^{8}$ writings, I follow narrative lines from Pesotta's life by sketching her pen-portrait. As I have written elsewhere, however, drawing on Arendt's ideas about meaning and understanding, ' 'a portrait can reveal meaning without defining it'. ${ }^{10}$ What I mean here is that a pen-portrait, like a painting, can open up a performative scene, a dialogic space wherein the subject, the researcher and the reader meet, interact and negotiate meaning about subjects and their world. In this light the portrait becomes a site of mediation and communication enabling the emergence of multiple meanings and traces of truth. Moreover the auto/biographical subject of the analysis, Pesotta in the case of this

\footnotetext{
${ }^{4}$ Julia Kristeva, Hannah Arendt, trans,. Ross Guberman (New York: Columbia University Press, 2001), 41.

${ }^{5}$ Olivia Guaraldo, Storylines: Politics, History and Narrative from an Arendtian Perspective (Jyväskulä: Sophi, 2001), 214.

${ }^{6}$ Michel Foucault, 'Nietzsche, Genealogy, History', in The Foucault Reader, ed. Paul Rabinow, trans. D. Bouchard and S. Simon (Harmondsworth: Peregrine, 1986), 76-100.

${ }^{7}$ See Juan Jose Castillo, 'The Memory of Work and the Future of Industrial Heritage: New Issues Five Years Later', Forum Qualitative Sozialforschung / Forum: Qualitative Social Research, 12 no. 3 (2011), Art. 3.

${ }^{8}$ Liz Stanley first introduced the slash in auto/biography in 1992, as a grammatical mode of denoting the porous boundaries between autobiography and biography as sub-genres of life writing. See Stanley, The Auto/biographical I (Manchester: Manchester University Press, 1992).

${ }^{9}$ Arendt, The Human Condition (Chicago: University of Chicago Press, 1998/1958), 324.

${ }^{10}$ Tamboukou, In the Fold, 57.
} 
paper, far from being essentialised, pinned down in a fixed subject position, or encased within the constraints and limitations of her story, becomes a "narrative persona', ${ }^{11}$ who responds to the theoretical questions and concerns of the researcher without necessarily validating them with 'the evidence of experience'. ${ }^{12}$ Still by following storylines from Pesotta's life I explore a crucial question that Adriana Cavarero has raised in responding to Arendt's take on narratives: 'does the course of every life allow itself be looked upon in the end like a design that has a meaning?'13

Since I have already referred to women workers and the cultural life of the working classes, I should also clarify that my take on both 'gender' and 'class' follows trails of assemblage theories. ${ }^{14}$ I have written elsewhere at length about this approach, particularly framing it within the field of gender and education. ${ }^{15}$ What I want to highlight here is that both 'gender' and 'class' are not conceptualised as reified generalities, but as assemblages of components that form relations of interiority and exteriority within and between them. Moreover, although assemblages are formed by multifarious and heterogeneous components and their relations, neither assemblages nor their components are reducible to each other. Components are, rather, independent of their assemblages and they can stand without them. In this light, assemblages and their components hold together as a dynamic formation: they are traversed by 'lines of flight' and are in a continuous process of 'becoming other'. As crucial notions in Deleuze and Guattari's philosophy, 'becomings' and 'lines of flight' offer new conceptual ways through which we can theorise resistance, accommodation and agency. ${ }^{16}$ As I will further argue, Pesotta's autobiographical narratives are saturated and traversed by 'lines of flight' that keep uprooting her from geographical, social, political and cultural territories; it is therefore charting lines of flight in becoming a woman, an anarchist, a garment worker, a trade-union activist and a writer that I will now turn.

\section{Rose Pesotta: a pen portrait of an anarchist trade-union leader}

Born in a well-off Jewish family in November 1896, Pesotta grew up in Derazhnya, a small town in the Ukraine. She received a relatively good education, both formal and informal, and was inculcated in the radical underground democratic circles of pre-revolutionary Russia, alongside her older sister Esther, who migrated to the US in 1907. Escaping an arranged marriage, Pesotta followed her in November 1913. In her autobiography Days of our Lives Pesotta has vividly painted her early revolutionary activities, which were interestingly very much related to enlightenment and education:

\footnotetext{
${ }^{11}$ Ibid., 179.

${ }^{12}$ Joan Wallace Scott, 'The Evidence of Experience', Critical Inquiry 17 (1991): 773-97.

${ }^{13}$ A. Cavarero, Relating Narratives: Storytelling and Selfhood, trans. Paul A. Kottman (London: Routledge, 2000), 1.

${ }^{14}$ See Manuel DeLanda, A New Philosophy of Society: Assemblage Theory and Social Complexity (London: Continuum, 2006).

${ }^{15}$ Tamboukou, In the Fold.

${ }^{16}$ See Gilles Deleuze and Felix Guattari, A Thousand Plateaus: Capitalism and Schizophrenia, trans. Brian Massumi (London: Athlone Press, 1988). See also Tamboukou, In the Fold, for a deployment of these notions in the field of gender and education.
} 
I was fifteen then, old enough to have been accepted as a full-fledged member of our secret circle. I had learned and changed a good deal since the days when Esther used me as a carrier of forbidden leaflets wrapped around my middle. Now I was taking an active part in the propaganda to enlighten the people, reading aloud to the illiterate and teaching some of them to read and write. ${ }^{17}$

Pesotta's decision to escape to the US was coloured by high hopes of freedom, but life was not easy for a young migrant woman arriving in New York in the first decade of the twentieth century, shortly after the tragedy of the Triangle fire. ${ }^{18}$ Through her sister's letters, Pesotta had already an idea of women workers' struggles in the garment industry:

... in December Esther sent news of a different sort. She was taking part in a big sabastovka, a strike with twenty thousand girls like herself, all shirtwaist makers, in protest against wage-cuts and unjust working conditions. Father read aloud a recital of her experiences - how she had attended a mass meeting ... where the girls took things in their own hands by voting a 'walkout' in the whole shirtwaist industry of New York. ${ }^{19}$

Pesotta's reference to her sister's letter skilfully inserts some crucial moments in women's labour history in the plot of her autobiographical narrative. Clearly the epistolary reference of a supposedly ignorant young girl in pre-revolutionary Russia, directly refers her American readers to a critical event in the history of the labour movement, the 1909 Shirtwaist Makers' Strike in New York, which came to be known as 'the Uprising of the Twenty Thousand'. Pesotta refers to this strike in passing, as she is clearly versed in the body of labour literature that had already been amassed around it and tacitly anticipates that her readers know about it as well. Still, by referring to it, she adumbrates the historical context within which her own political work is situated. Indeed the Shirtwaist Maker's Strike was a crucial turning point in the history of the International Ladies Garment Workers Union (ILGWU). Over the years the commemoration of the strike had become an event that gave women workers an opportunity to reflect upon the history of their union and take heart in confronting the bleak circumstances of their present. As Edward Casey has aptly put it, "commemorating is an intensified remembering ... it enables us to honour the past by carrying it intact into new and lasting forms of alliance and participation' ${ }^{20}$

Here it is important to highlight Fannia Cohn's work in the ILGWU Educational Department in creating an archive of memories of struggle. Cohn (1885-1962) was an influential figure in the trade union movement in the garment industries in the United States in the first half of the twentieth century. Coming from a wealthy Russian Jewish family, she emigrated to the US in 1904, got actively involved in trade union struggles and became the first woman vice-president in the history of

\footnotetext{
${ }^{17}$ Pesotta, Days of Our Lives (Boston: Excelsior Publishers, 1958), 191-92.

${ }^{18}$ The Triangle Shirtwaist Company Fire, at the heart of Greenwich Village in Manhattan, New York, is one of the most tragic events in American Labour History: 146 young women garment workers died on 25 March 1911 while trying to escape the burning building within which they were locked. This horrible event led to a series of changes in labour legislation and occupational safety standards but also marked the rise of women's active involvement in the labour histories of the twentieth century. For a historical account of the event, see amongst others, L. Stein, The Triangle Fire (Ithaca: Cornell University Press, 1962).

${ }^{19}$ Pesotta, Days of Our Lives, 169.

${ }^{20}$ Edward Casey. Remembering: A Phenomenological Study (Bloomington and Indianapolis: Indiana University Press, 2000), 257.
} 
the ILGWU, between 1916 and 1925. She was instrumental in organising the ILGWU's educational and cultural activities and served as executive secretary of its Educational Department between 1918 and 1962. ${ }^{21}$ During the many years of Cohn's tireless work in advancing workers' education, the 'Uprising of the Twenty Thousand' was not only established as an annual commemorating event, but also became a central theme of the different versions of the ILGWU history that were written and published either as books or pamphlets. ${ }^{22}$ Moreover, the force of the strike inspired a number of labour skits that Cohn herself wrote, directed and produced as part of the ILGWU cultural activities ${ }^{23}$ and also became the topic of historical fiction writing, as Malkiel's Diary of a Shirtwaist Striker. ${ }^{24}$ The strike was finally analysed and theorised in a series of journal articles, course-works and essays, as well as doctoral and master's dissertations in the growing research literature of the labour movement. ${ }^{25}$

In thus reading Pesotta's auto/biographical narratives, we need to map their political, historical and cultural context, but we also need to situate the author and her work in a genealogical line of influential women organisers, who actively intervened in the male-dominated trade union politics at the beginning of the century in the US. Indeed, what is particularly striking about Pesotta is the fact that she was writing as a highly involved political actor and not as a student or an academic, as was mostly the case with the existing literature of the time. But what were the conditions of possibility for Pesotta to emerge as an organic intellectual ${ }^{26}$ of the labour movement? This is how I take up the thread of Pesotta's political biography again.

On arriving in New York in November 1913, Pesotta found a job as a seamstress and started learning English in a night school class for foreigners.

\footnotetext{
${ }^{21}$ See Ricki Carole Myers Cohen, Fannia Cohn and the International Ladies' Garment Workers' Union (PhD thesis, University of Southern California, 1976).

${ }^{22}$ See Fannia M. Cohn, The International Ladies Garment Workers Union: Its History and Development (21 chapter essay, n.d.). Fannia M. Cohn papers. Manuscripts and Archives Division. The New York Public Library. Astor, Lenox, and Tilden Foundations. (FCP/NYPL, Writings, 1920-1950). For an early published record of the ILGWU History, see Louis Levine, The Women's Garment Workers' Union (New York: Huebsch, 1924), for later versions between 1920-1950s, see Max D. Danish, The Story of the ILGWU (New York: ILGWU, 1947); There is also a series of pamphlets on a range of ILGWU Locals. For a comprehensive bibliography see the Cornell University School of Industrial and Labor Relations (IRL), http://www.ilr.cornell.edu/ILGWU/bibliography.html.

${ }^{23}$ The Uprising of the Twenty Thousand: A Play with Pageant Implications, by Fannia M. Cohn, 1934, five scenes, 45 pages (FCP/NYPL, Writings, 1920-1950).

${ }^{24}$ Theresa Serber Malkiel, The Diary Of A Shirtwaist Striker: A Story Of The Shirtwaist Makers' Strike in New York (New York: Co-operative Press, 1910).

${ }^{25}$ For early accounts of this literature, see amongst others, Theresa Wolfson, 'The Woman Worker and the Trade Unions' (PhD dissertation, Brookings Institution, 1926), also published in the same year by International Publishers in New York; Julia Saparoff Brown, Factors Affecting Union Strength: A Case Study of the International Ladies' Garment Workers' Union, 1900-1940 (PhD. diss., Yale University, 1942); Hyman Berman, The Era of the Protocol: A Chapter in the History of the International Ladies' Garment Workers' Union, 1910-16 (PhD. diss., Columbia University, 1956) and J.B.S. Hardman, 'The Needle-Trades Unions: A Labor Movement at Fifty', Social Research (Autumn 1960): 321-58.

${ }^{26}$ I refer here of course to Gramsci's distinction between traditional and organic intellectuals. See Antonio Gramsci, Selections from the Prison Notebooks (London: Lawrence and Wishart, 1971).
} 
As recounted in the autobiography of her early years, she was not particularly impressed by the pedagogic practices of this school:

I made painfully slow progress at night school.... Our teacher, of immigrant stock herself, a colorless young woman, obviously disliked her pupils, most of whom were adults with some education from their former homeland, but who could not readily adopt her way of pronunciation... I hung on to the end of the first term. But when summer vacation came I devised my own method of learning the new language. In the East Ninety-sixth Street Public Library Harlem branch, I found an excellent Russian section, and began re-reading my favourite authors.... And meanwhile I learned to read the daily press and magazines.... ${ }^{27}$

Pesotta's revolutionary spirit was clearly not restricted to challenging educational practices. She enthusiastically immersed herself in the agonistic spirit of her times and soon became involved in trade union politics:

On May Day eve we were working in a small dingy dress shop at Wooster and Grand Streets. The owner and his family toiled all hours of the day, night, and holidays. But his employees, a half-dozen of us union girls insisted on working only forty-nine hours a week. We had decided to take part in the big labor parade next day.... When the boss got wind of this, he delivered an ultimatum. 'Everybody must come to work tomorrow. Whoever doesn't show up is fired.' We answered with a shrug of our shoulders. In the morning we met as agreed in front of the shop, and marched in a body.... En route we came to the scene of the tragic Triangle Shirtwaist Company Fire.... As we halted there, several of our union officers spoke briefly, in Yiddish, Italian and English: 'Here they died, martyrs to greed. But we who live vow that shall never happen again. Let's dedicate ourselves to the cause of labor.... 28

Pesotta and the other union girls returned to their shop the following day and asserted their right to work as union members, while the agonistic politics of her early days as a dressmaker would decidedly shape the course of her life. As her friend and comrade Clara Rothberg remembers those early days of activism: 'Rose and I would work all day at the sewing machines and then march on the picket lines from 1:00 a.m. to 5.00 a.m. and then return at 7:00 a.m. to a full day of work in the shop. ${ }^{29}$

Pesotta's active involvement in two historically important ILGUW locals, Local 25 and Local 22, ultimately paved her way to the union hierarchy: following Cohn's lead, she became the third woman ever elected as vice-president of the ILGWU and served in this position as the only woman member of the Executive Board between 1934 and 1942. But as I will discuss later on, the harshness of the gender politics within the union eventually led her to resign from the leadership role, although she went on being politically active both in union matters and in wider political circles till the very end of her life. Indeed her involvement in the Sacco and Vanzetti case ${ }^{30}$ and her lifelong correspondence with Emma Goldman

\footnotetext{
${ }^{27}$ Pesotta, Days of Our Lives (Boston: Excelsior Publishers, 1958), 246-7.

${ }^{28}$ Ibid., $250-1$.

${ }^{29}$ Cited in Elaine Leeder, The Gentle General, Rose Pesotta, Anarchist and Labor Organizer (New York: State University of New York Press, 1993), 19.

${ }^{30}$ Sacco and Vanzetti were two Italian anarchists who were convicted of armed robbery and murder in Massachusetts in 1920. Their trial was highly controversial and the anarchist movement in the USA formed a defence committee in which Pesotta was an active member. Despite a series of appeals, however, Sacco and Vanzetti were executed in 1927.
} 
are revealing of the political questions and issues that were prevalent in the US political scene in the first half of the twentieth century. ${ }^{31}$

Upon withdrawing from the leadership of the ILGWU in 1942, Pesotta followed 'lines of flight' from the sexism of her union by throwing herself into writing: her political autobiography, Bread upon the Waters, was published in 1944, while her more private recollections of her early years in Russia, Days of Our Lives, appeared in 1958. Indeed, Pesotta delved into the world of writing and lecturing while also going on with her work as a dressmaker. As she wrote to her friend Sue Adams on November 11, 1943:

As for myself I am doing nicely, thank you, working in the shop during the season and staying at home in slack time. Doing what? You will ask.... I am writing a book. It is almost done, save the last chapters. It is about my activities in the last ten years.... It is written so that it can be understandable to the women whom I organized and their like, who would never read such books as the Needle Trades by Siedman which are too technical for them. ${ }^{32}$

As already noted in Pesotta's letter above, the possibility to combine writing and sewing was enabled by the particular material conditions of garment workers: the seasonal character of their work and particularly the slack periods would allow them to intervene in the rhythm of their work and life. What is also interesting in the above epistolary extract is that in writing the book as an intellectual, she was very clear and strategic about her audience: the book was explicitly addressed to women who were otherwise tacitly excluded from the usual literature in the field, although it would also become part of the academic literature of the time. As Amy Hewes, a Mount Holyoke economist and Bryn Mawr faculty member, was writing to Pesotta on 15 January 1944, shortly after Bread upon the Waters had been published: 'Are you enjoying all the nice things that are being said about your book? My students are reading it with great pleasure and I am sure it is the means of interpreting unionism to them. ${ }^{, 33}$

But apart from her two published autobiographical books, Pesotta's papers at the New York Public Library Archives include numerous forms of political and creative writing such as essays, novellas, short stories, book reviews, poetry and an unfinished novel, as well as two incomplete autobiographical manuscripts; these writings go back to the early years of arriving in New York and continue throughout her life. A preoccupation with the importance of education is central in these writings, which seem to have been inspired by her involvement in 'The Writing Table' of an Art Workshop between 1930 and 1932; this was a creative writing group of 10 working women, who met on Thursday evenings at East $37^{\text {th }}$ Street, under the tutelage and direction of William Mann Fincke, an influential figure at the Brookwood Labor College for Workers, an educational institution that was organically related to the trade union movement in general and the ILGUW in particular. ${ }^{34}$ According to Fincke, creative writing means a forceful way of

\footnotetext{
${ }^{31}$ For Pesotta's wider political work, see Elaine Leeder, The Gentle General.

${ }^{32}$ Letter from Rose Pesotta, dated November 11, 1943, (RPR/ NYPL/General Correspondence, 1943, April-).

${ }^{33}$ Letter from Ay Hewes to Rose Pesotta, dated January 15, 1944, (RPR/ NYPL/General Correspondence, 1943, April-).

${ }^{34}$ For a history of the college, see amongst others, Charles F. Howlett, Brookwood Labor College and the Struggle for Peace and Social Justice in America (Lewiston, NY:Edwin Mellen Press, 1993).
} 
expressing and developing working-class culture in a way that would have a wider impact on the formations of culture:

It would seem logical that the experience of industrial workers in writing groups established throughout the country might have a significant event upon our national literature.... In the beginning of articulateness among those more close to the borderline of survival and those who participate firsthand in processes productive of life's necessities, we have the promise of a vastly greater literary perspective. ${ }^{35}$

Here again, Cohn's close involvement with the founding and development of Brookwood College as an educational institution of and for the workers has to be noted. ${ }^{36}$ Pesotta's educational trajectory was clearly influenced by Cohn's vision and politics around workers' education: two years after completing the Bryn Mawr summer school, she became one of the first students of Brookwood College, which she attended between 1924 and 1926, at the very beginning of its educational history. Education, both formal and informal, had therefore been catalytic in Pesotta's life; having herself greatly benefited from the ILGWU's attention to the importance of workers' education, it is no surprise that during the eight years of her leadership as an ILGWU vice-president, she took great interest in promoting and supporting workers' education, by organising educational and cultural activities and events. In her view, workers' education should be conceived as a multi-level space where workers could not only develop as assertive trade unionists and responsible citizens, but also and perhaps more importantly as fully cultivated human subjects:

For toilers of hand and brain, the union is both primary school and university rolled into one. It is there that they learn how to plan and to assume responsibility. From the struggles of the organisation there is firmly impressed in them lessons, which they could never have hoped to learn in any classroom. But the International recognized that our members could develop into much more effective trade-unionists and citizens, when to the experience they had gained by day activities of their unions there was added the benefit that could be derived from a serious study and discussion of important social problems under the guidance of a competent instructor. Nor did we ignore the stimulating effect that the enjoyment of literature, the drama and music would have on our members' intellectual and emotional development, as well as their value in fostering a sympathetic understanding and sensitive approach to others. ${ }^{37}$

Pesotta's ideas about workers' education were clearly framed within Dewey's philosophy of progressive education as enacted by two extraordinary ILGWU women: Juliet Stuart Poyntz, educational director from 1915 to 1918, and Fannia Cohn, as already discussed earlier. It has to be noted here, however, that by the time Pesotta had climbed the hierarchy of the union many things had changed in its educational vision and practices. As Susan Stone Wong has succinctly put it, the history of the ILGWU's educational movement could be charted as a downside curve 'from soul to strawberries'. ${ }^{38}$ What started in the 1920 s as a vision for workers' education that would become 'the soul' of the union movement for social change was ultimately transmuted to a narrow project of 'labour education' as a source of

\footnotetext{
${ }^{35}$ Cited in Hollis, Liberating Voices, 127.

${ }^{36}$ Fannia M. Cohn Papers (FCP/ NYPL/Brookwood Labor College, 1924-1938).

${ }^{37}$ 'Education, Recreation and Health', unpublished essay in (RPP/NYPL/Writings).

${ }^{38}$ Susan Stone Wong, 'From Soul to Strawberries: The International Ladies' Garment Workers' Union and Workers' Education, 1914-1950', in Kornbluh and Frederickson, eds., Sisterhood and Solidarity, 37-74.
} 
material happiness, aiming to instruct workers to cope with their world instead of inspiring them to change it. Here, however, although I can see the context of Stone Wong's pessimistic sketch of the intellectual decline of the ILGWU's vision for workers' education, my research with Pesotta's and Cohn's papers has revealed a much more complicated cartography of the movement for workers' education in the US. I expand elsewhere on this. ${ }^{39}$ Here, however, I want to focus on the stormy two-year period between 1920 and 1922, within which Pesotta's 1922 letter from Bryn Mawr was written.

\section{Microhistories of struggle}

The 1920s was the decade when American women gained the right to vote, but this victory seems to have denigrated rather than strengthened the feminist movement, since many of the suffragists left the States to go to Europe 'leaving American working women especially vulnerable to sexist labor practices' ${ }^{40}$ The 1920 s was also a low period for the trade union movement: in her unpublished 'History of ILGWU' Cohn has written in detail about the 1920-1922 period, which she has identified as 'The Employers' Offensive', discerning three waves in its deployment. ${ }^{41}$ During the first wave, which lasted between October 1920 and February 1921, 'various manufacturers' associations in different parts of the country made attempts to cut wages and revise the agreement in their favor', ${ }^{42}$ but in most cases such attempts were fought back by harsh negotiations and, in some cases, local strikes as in Boston and New York.

The second wave was launched in April 1921 aiming at 'a reduction of wages, reestablishment of the piece-work plan and greater freedom to hire and fire' ${ }^{43}$ This wave was met with 'defensive strikes', ending up in a compromise wherein ILGWU was bound to 'a promise of better work and high productivity' through a 'Supplementary Agreement', which did not go down well with the garment workers, although it was ultimately accepted as 'a necessary defensive measure'. ${ }^{44}$ The second wave ended dramatically in August 1921 with the beginning of the Philadelphia strike, 'one of the bitterest struggles in the local history of the trade', which ended with a humiliating defeat after 26 weeks; this defeat, however, was overturned in March 1923, when after only a two-week strike, the Philadelphia dress and waistmakers won 'a substantial victory'.

The third wave started in October 1921 and was initiated by a conference of the New York Cloak and Suit Manufacturers' Protective Association in Atlantic City, where employers returned to the demands of the first wave, including wage-cuts and the reintroduction of piece-work amongst other reactionary measures. The response was a massively voted general strike by the cloak makers in November 1921, when 55,000 workers left their shops in New York, while the strike movement spread across a number of US cities, reaching its peak in December 1921,

\footnotetext{
${ }^{39}$ Tamboukou, 'The Ideal Materialism of Fannia Cohn', paper presented at the Gender and Education bi-annual conference, South Bank University, April 2013.

${ }^{40}$ Hollis, Liberating Voices, 11.

${ }^{41}$ 'History of ILGWU', unpublished essay, Chapter 11, 81-84, (FCP/NYPL/Writings, ca. 1920-1950).

${ }^{42}$ Ibid., 81.

${ }^{43}$ Ibid., $81 \mathrm{~A}$.

${ }^{44}$ Ibid.
} 
with 75,000 women's garment workers on strike, defending previously won labour rights. This national upheaval ended triumphantly in January 1922 with the employers finally agreeing 'to re-instate the week-work system and the 41-hour week'. 45 The January agreement seemed to be a temporary victory, however, as the spring and summer of 1922 were slack periods in the trade, unemployment rose and economic conditions deteriorated, a decline that was reflected in the ILGUW's membership numbers (from 105,000 in 1920 to 93,000 in 1922). But by the fall of 1922, the depression in the garment trade had seen its worst days and signs of improvement started emerging.

While Cohn's History of ILGWU maps the micro-political context of the 1920-1922 critical period, Pesotta's unpublished writings have painted more vivid pictures of the 'Employers' Offensive' in the form of fictional diary writing:

Monday 7 A.M The alarm clock rings. How nice and warm is my bed ... but I cannot stay in any longer - may fall asleep again ... I simply must find a job ... I dress hurriedly ... no time for breakfast ... shall have a coffee down town.... On the way I shall buy a newspaper. Riding in the subway, there is enough time to look over the Want section. Am pushed out of the subway by a compact mass of humans ... all in a hurry ... either having job, or hurrying to be the early applicants. In the proletarian Ritz [the Automat cafeteria in the Garment Centre] I meet friends. Many are out of work ... usually this is our busy season, but now it seems there will be no busy season for us ... we must hurry ... time is short... Sipping the hot coffee, we select an ad to answer, to get there in time ... I hate to stand in line begging for a job....

Tuesday, 7 A.M. I do not wait for the alarm clock to wake me. Am up early to get to work on time.... My friend is waiting at the 'Ritz', we are happy ... going to work ... not looking for work.... In the newly found shop again. The employer seems to be in a bad humor. He does not even greet us. The workers throw hostile glances towards our section ... a bad sign ... we work till noon. My work finished, I take it over to the counter; there is nothing more for me - no more work! Must again go out to look for another job. I help my friend to finish her garments and at noon we are in the market among the unemployed again....

Wednesday, 7 A.M. Again the cursed alarm clock, the newspaper Help Wanted section, the 'Ritz' - a new job. This time it is a dark and gloomy joint. Everybody seems to have an idea that hers is the best voice - it is a Bedlam. I do not even consider remaining here - shall finish the garment begun in the morning. At noon in the market, shall inquire among friends if anyone has heard of a job.

Thursday, Ditto A.M. Work, Work, Work, I must go to work. Early to rise and late to bed does not go very well together; I have a blooming headache, but the new job is a fact - I am going to work today.... As it was predicted at the 'Ritz' the rush is over in my newfound factory. Nothing doing for the new worker. Those who have worked in the shop are getting the preference. My garment finished, about ten o'clock in the morning, I must leave.... It is raining, I shall seek shelter at the office of the union. At the office someone has a job for me, but he seems to be reluctant, telling me that it is a tough job. The employer is a lady and everyone seems to hesitate about going to work for a LADY-BOSS. Personally I am prejudiced against lady magistrates, lady

managers and lady bosses. Somehow all three have given me a dirty deal - not to be forgotten in a long while.

${ }^{45}$ Ibid., 83. 
Friday 7 A.M. Luckily it is the last day of the week. The strain is nerve wrecking! ... The day is coming to an end. I am exhausted ... my work is still being examined. It is the end.... I shall quit now, this very minute.... At five-thirty I tell my LADY BOSS that we seem not to like each other - so I quit. She is glad. So am I.... Except that next week I shall be kept busy running from place to place collecting my earnings

- will have no time to look for work. ${ }^{46}$

Pesotta's fictional diary ends with some reflections of how 'by 1923 the ILGWU had the situation well under control, organizing the industry during the General Strike, being the first to introduce the Forty Hour Week into dress manufacturing' ${ }^{47}$ Her politico-historical fiction creates a textual rhythm-analysis of workers' daily experiences in the garment industry and vividly complements Cohn's structural analysis of the trends and forces in the garment industry. What is particularly interesting in both Cohn's and Pesotta's writings is the way they highlight the incessant waves of 'highs and lows' in the micro-histories of the garment industry: the ongoing whirl of employers' attacks and workers' resistance, retreat and also accommodation strategies. Despite the differences in the genres and modes of their writings, there are also interesting commonalities: Pesotta's reference to women workers' awareness of 'the famine in Russia' in her Bryn Mawr letter is a point that Cohn highlights in concluding the microhistory of the 'Employers' Offensive':

On November 15, 1921 the cornerstone of a six-story building, the new Home of the International was laid at 3 West $16^{\text {th }}$ Street, New York City. A few weeks later the International dispatched a shipload of foodstuff for the victims of a famine in Soviet Russia. The cost of the gift was borne by members of the I.L.G.W.U., all of whom donated a half day's pay for this purpose. ${ }^{48}$

Cohn's concluding paragraph of the two years of 'the Employers' Offensive' is a manifestation of the writer's intention to highlight two positive events at the end of a rather gloomy period: the foundation of a new home for the union and an act of solidarity. Bryn Mawr was also founded in June 1921, at the heart of the second wave of 'The Employers' Offensive': Pesotta's enrolment in the summer of 1922 should thus be framed within the ILGWU's counter-strategies, including the education of its future leaders. The movement for workers' education thus emerges as creative and forward-looking in both women's writings: it transcends material and discursive limitations and creates new conditions of possibility for workers' lives.

But one should not be over-celebratory here vis-à-vis the trade union politics of the period. Despite its title and women-based rank-and-file constitution, the ILGWU was unsurprisingly led by men with women's voices and their presence was often ignored, marginalised, stifled and often suppressed.

'Soon I will be with you again', Pesotta writes at the beginning of her letter, working during the day and trying 'to organize the non-organized' in the evening. Feminist labour historians have used up a lot of ink on looking into the troubled

\footnotetext{
46، A Garment Worker's Diary’, unpublished essay in (RPP/NYPL/Writings), emphases in the text.

${ }^{47}$ Ibid.

${ }^{48}$ History of ILGWU, Chapter 11, 84, (FCP/NYPL/Writings).
} 
history of gendered politics within the labour movement in general and garment trade unionism in particular. ${ }^{49}$ They have particularly highlighted the huge difficulties that women had to grapple with not only in trying to unionise a volatile body of vulnerable migrant women workers, but also in struggling against the sexism of their union.

Using the above epistolary phrase 'organizing the non-organized' as the title of her well-known essay 'Organizing the Unorganizable', Alice Kessler-Harris has particularly looked at the experience of three notable ILGWU organisers, namely Pauline Newman, Fannia Cohn and Rose Pesotta, since 'taken together their lives reveal a persistent conflict between their experiences as women and their tasks as union officers' ${ }^{50}$ What is highlighted and carefully documented in Kessler-Harris's influential work is 'the persistency of the conflict', rooted in systemic problems and not in personal whims or idiosyncrasies. As she has succinctly observed, tensions between women and men in trade unions have been a historical constant, but the 1920s was a particularly interesting period given women's recent enfranchisement as well as the fact that in the 1920s women's presence in the labour force had been finally admitted as a given, albeit reluctantly so, by trade unions. As a result, women were welcome 'as dues paying members, tolerated as shop-level leaders and occasionally advanced to become business agents and local and international officers', ${ }^{51}$ but they were marginalised within the trade union structures and were practically excluded from its leadership. Moreover, there were no overall organisational structures or strategies in how to recruit, keep and organise women workers. This task fell to a few women organisers, like Cohn, Pesotta and Newman, who very much drew on educational and cultural activities not only to attract women garment workers to the union, but more importantly to persuade them to stay.

Apart from the intellectual influence that Cohn had upon Pesotta's formation as a union activist, the two women were in constant correspondence around educational activities: 'It is good to receive your messages, because they are full of life, vigor and motion and that is exactly what we need now in our movement', 52 Cohn wrote to Pesotta on 13 April 1934, while sending her 'material for her classes', which included manuscripts for 'study groups and lecture audiences', but also short theatrical pieces in the spirit of the workers' theatre movement, which was in its heyday in the 1930 s in the US. ${ }^{53}$

In this context, Cohn's micro-histories, as well as Pesotta's autobiographies, letters and unpublished writings, leave textual traces of women unionists' struggle to promote women workers' education and organise social and cultural activities, through which the grey and cold union spaces were transformed into warm places, where women garment workers felt welcomed and protected and were thus

\footnotetext{
${ }^{49}$ See Nancy Green, Ready to Wear, Ready to Work: A Century of Industry Immigrants in Paris and New York (Durham and London: Duke University Press, 1997), Alice Kessler-Harris, Gendering Labor History (Urbana and Chicago: University of Illinois Press, 2007), Mari Jo Buhle, 'Socialist Women and the "Girl Strikers", Chicago 1910', Signs 1, no.4 (1976): 1039-51 and Nancy Schrom Dye, 'Feminism or Unionism? The New York Women's Trade Union League and the Labor Movement', Feminist Studies 3, nos 1/2 (1975): 111-25.

${ }^{50}$ Kessler-Harris, Gendering Labor History, 38.

${ }^{51}$ Ibid.

${ }^{52}$ Letter from Fannia Cohn to Rose Pesotta, dated April 13, 1934 (RPP/NYPL/General Correspondence, 1934, March-May).

${ }^{53}$ Hollis, Liberating Voices, particularly Chapter 4.
} 

encouraged to become union members. Women garment workers were indeed longing for respectability, their desire being beautifully expressed in the words of Hannah Shapiro, a leading figure of the 1910 Chicago Garment Workers' Strike: 'we had to strike ... we have to be recognised as people and, really, we struggled; it wasn't easy' ${ }^{54}$ It is this desire for women workers being 'recognised as people' that was at the heart of Cohn's educational planning in the $1920 \mathrm{~s}$, while attempting to transform the union from 'a picture of middle-aged men sitting in smoky taverns drinking and arguing interminably over the tactics of union organizing ... to a community in which [women workers] could learn, meet friends and have fun'. ${ }^{55}$

But what these pioneers of women workers' education had not realised at the time is that in their attempt to reconfigure the trade union movement in a way that could become attractive and welcoming to women workers they were inadvertently introducing gendered ideologies, discourses and values that the male union leaders were happy to adopt and exploit, but these same leaders were totally reluctant to allow them to challenge the gendered hierarchies of the union. ${ }^{56}$ It is not surprising that Pesotta, like Cohn before her, fell out with the union and was forced to resign from its leadership.

In the wider political sphere, the 1917 Russian revolution had become an inspiring force for the left strands of the labour movement but it had also created a climate of 'Red Scare' terror and anti-immigrant sentiment, as manifested in Emma Goldman's and Alexander Berkman's deportation in 1920, and culminated in the execution of Italian anarchists Sacco and Vanzetti in 1927. As an anarchist migrant worker herself, Pesotta was very much immersed in the 1920 s political turbulence as well as the fierce resistance against the climate of terror and political persecution of anarchist and socialist labour leaders. As a matter of fact Pesotta's involvement in the Sacco and Vanzetti defence committee started in an ILGWU meeting in Boston in the autumn of 1922, just after she had completed the Bryn Mawr summer school. Her letter of August 1922 clearly shows that she was seriously preoccupied with this case and, as Leeder has noted, she had already 'researched the case for her Local 25 executive board'. ${ }^{7}$ Although Pesotta's overall political activities go beyond the scope and limitations of this paper, it is important to situate her Bryn Mawr letter within a wider socio-political context of xenophobia, racism and labour movement turbulence.

\section{To the letter: narratives, truth, politics}

Having sketched Pesotta's pen-portrait within the landscape of her geographies and times, what I want to do in this section is to return to the letter and by following its prose to reconsider the analytical themes of this paper as they appear in the plot of the epistolary story. In doing so I take up Arendt's thesis that narratives flesh out

\footnotetext{
${ }^{53}$ Hollis, Liberating Voices, particularly Chapter 4.

${ }^{54}$ Rebecca Sive in conversation with Hannah Shapiro Glick, in Sive, 'Identifying a Lost Leader: Hannah Shapiro and the 1910 Chicago Garment Workers' Strike', Signs, Journal of Women in Culture and Society 3, no. 4 (1978): 936-39.

${ }^{55}$ Wong, 'From Soul to Strawberries', 44.

${ }^{56}$ For an interesting analysis of sexism in industrial unionism in the 1930 s, see Hartman Sharon Strom, 'Challenging "Woman's Place": Feminism, the Left and Industrial Unionism in the 1930s', Feminist Studies 9, no. 2 (1983): 359-86.

${ }^{57}$ Leeder, The Gentle General, 43.
} 
theoretical abstractions, reveal meaning without necessarily defining it and open up political spaces of communication and action. As Arendt has succinctly put it in her influential essay Truth and Politics: "philosophical truth can become "practical" and inspire action without violating the rules of the political realm only when it manages to become manifest in the guise of an example'. ${ }^{58}$ What I have argued throughout this paper is that Pesotta's autobiographical writings constitute such an exemplary case, 'a design of a life that has a meaning' and it is to her letter that I now return.

What we first read in its opening paragraph is that this letter is 'the last you will receive from Bryn Mawr'. As a fragmented archival document, the letter is a trace of a correspondence that is now lost, but it is also a sign that writing was crucial for women workers: it gave them the opportunity to communicate with others, reflect on their experiences and reposition themselves as subjects. ${ }^{59}$ An intense spatial awareness was central in these writings, as forcefully expressed in the first paragraph of Pesotta's letter where the spaces of the college are juxtaposed with 'the dusty city' and 'the shop'. Indeed a number of photographs as well as a film in the existing literature around Bryn Mawr have visually captured the spatial dimension of women workers' educational experiences in the idyllic landscapes of the campus. ${ }^{60}$ Summer school students reading in the portico, sitting and discussing in the cloisters, taking a poetry-reading class on the lawn or having an economics discussion group under the trees allow visual glimpses of other spaces and other times in women workers' lives, surely different from the cramped urban sweatshops where they used to work. Women workers expressed their love for Bryn Mawr's natural surroundings in their autobiographies and poetry. ${ }^{61}$

Previously in my work I have drawn on Foucault's notion of heterotopia ${ }^{62}$ to configure the first university-affiliated women's colleges at Cambridge as educational heterotopias, different spaces in the margins of mainstream institutions that disrupted the normality and linearity of traditional spaces and temporalities of femininity, allowing women to re-imagine their lives and actively intervene in the formation of the self. ${ }^{63}$ In this light the Bryn Mawr premises could be seen as transitional spaces, saturated by power relations and forces of desire and thus creating conditions of possibility for new subjectivities to emerge. But given the clearly articulated political aims and vision of the school in terms of actively nurturing and cultivating the will for social change, the open spaces of the Bryn Mawr campus can also be seen here as Arendtian public spaces where women could come together and by revealing their unique existence through 'words and deeds' they would constitute a body politic and work together for the foundation of freedom: "the political realm rises directly out of acting together, the sharing of

\footnotetext{
${ }^{58}$ Hannah Arendt, Between Past and Future: Eight Exercises in Political Thought (London: Penguin Books, 2006 [1961]), 243.

${ }^{59}$ Hollis, Liberating Voices.

${ }^{60}$ Smith, Women Workers, Rita Heller, The Women of Summer, documentary film, Hollis, Liberating Voices. There is further a rich collection of photographs at Bryn Mawr at the M. Carey Thomas Library at Bryn Mawr College.

${ }^{61}$ Hollis, Liberating Voices.

${ }^{62}$ Foucault, 'Des Espaces Autres', in Dits et ecrits 1954-1988, vol. IV, 1980-1988 (Paris:

Editions Gallimard, 1994), 752-62.

${ }^{63}$ Tamboukou, Women, Education and the Self.
} 
words and deeds ... action and speech create a space between the participants which can find its proper location almost any time and anywhere'. ${ }^{64}$

In this light, the student body was crucial in how the policies of the school evolved and changed during the two decades of its institutional history. As Hollis has pointed out, through their participation in administrative and curriculum committees the students succeeded in introducing a number of changes and programme additions: 'admission of African-American students in 1926, as well as waitresses and housekeepers of all races; an extracurricular poetry class; an expanded dramatic program; a "proletarian" literature course; and a "Marxist" instructor' ${ }^{65}$ Such additions and changes were often controversial and rigorously debated by the different sections of the student body. Lillian Herstein, a union labour teacher at Bryn Mawr, has vividly depicted some hot scenes from the debates around the admission of black students to the school:

I remember when we had the discussion at the school by the whole student body. One lovely red head from the South said that she herself had no prejudice, but if [people in her small town] learned that the school admitted Negroes no other girl from the community would be sent.... The students voted to admit Negroes. ${ }^{66}$

Equally controversial was the waitresses' admission debate, which was challenged not on racist but on moralistic and sexist grounds, since 'many of the working girls felt that waitresses were immoral; they made dates with the men they waited on'. ${ }^{67}$ Here again working-class solidarity prevailed in the persuasive argument of a New York factory girl: 'if they are immoral, it's because of the conditions under which they work. If they got wages instead of tips, they wouldn't have to smile at every man they waited on, they wouldn't be tempted. ${ }^{68}$ In the logic of the girls' argument, the struggle should not be about keeping waitresses out of the school, but about changing their working conditions.

What is particularly notable in the above-mentioned debates is that the school created conditions of possibility for political spaces wherein students could express their opinion, put forward all kinds of propositions - whether 'left' or 'right', 'progressive' or 'reactionary', 'radical' or 'conservative' - and feel free and fearless to persuade or be persuaded. As Arendt has noted: 'being seen and being heard by others derive their significance by the fact that everybody sees and hears from a different position'. ${ }^{69}$ The Bryn Mawr educational experience was thus crucially important in opening up political spaces wherein human beings appeared to the world 'through words and deeds' and found freedom through making new beginnings.

But the Bryn Mawr experience was not just about institutional structures, educational policies and curricular changes: 'Really, dear comrade, when I look back ... I find such a change in my thoughts', the letter goes on, flagging up the intense experiences of self-transformation that both women workers and faculty members

\footnotetext{
${ }^{64}$ Arendt, The Human Condition, 198.

${ }^{65}$ Hollis, Liberating Voices.

${ }^{66}$ Lillian Herstein, 'Equal is Equal Brothers', in Rocking the Boat: Union Women Voices 1915-1975, ed. Brigid O' Farrell and Joyce L. Kornbluh, 22 (New Brunswick: Rutgers University Press, 1996), 10-33.

${ }^{67}$ Ibid.

${ }^{68}$ Ibid.

${ }^{69}$ Arendt, The Human Condition, 57.
} 
of Bryn Mawr would undergo. Such changes were not just ephemeral but went on for life as Pesotta's pen portrait beautifully demonstrates. Moreover, after leaving Bryn Mawr, the students felt the need to spread their newly found knowledge and social awareness and they did it through a variety of channels and means, their trade unions, workplaces, neighbourhoods and wider communities. What is expressed in the letter as 'let me share with you my new discoveries' would become a lifelong endeavour. Here again Pesotta's activities in organising the educational and cultural activities of the locals she was in charge of constitute a brilliant example of how this sharing worked; but it is only because of and through her autobiographical writings that we even know about such activities: Pesotta's writings have become mnemonic traces of women's struggles in the history of the labour movement.

What is also worth remembering is that this 'sharing of new discoveries' was always coloured by different views, perspectives and disagreements. Such possibilities for living with difference emerged not just from intellectual discussions, ideological positions and mental attitudes but perhaps more importantly from the actual material conditions and spatial conditions of the school: 'the pulse of the US beats in Bryn Mawr at this very moment' the letter goes on, acknowledging that 'each state has its own way of living, with its joys and sorrows'.

But how exactly were such critical communities of difference sustained and what were the socio-political conditions that made them possible? The letter writer responds to such questions in her nuanced description of the various groups within the school: the Southern girls are 'born aristocrats' while 'the Northern group is rather more progressive'. It is obvious that the author sides with 'the radicals' while sympathising with the naivety of the 'revolutionary' faculty members. But although she is aware of the imbalance of power between the middle-class instructors and the working-class students, she does recognise the effects of Bryn Mawr's non-hierarchical pedagogy: "they are not here to "put things over us" they simply explain us what we do not know and then we ourselves are discussing the question and if some of us are wrong, the instructor will always call our attention', she notes.

What we can also see here are vibrant signs of cross-class encounters and solidarity that would historically mark the Bryn Mawr experience. In adopting the British tutorial approach, ${ }^{70}$ the school opened up spaces for dynamic encounters between middle-class college undergraduates and working-class summer students. According to M. Carey Thomas, Bryn Mawr's founding president, college women were best suited to become tutors of working-class students, since 'themselves just emerging from the wilderness, know best of all women living under fortunate conditions what it means to be denied access to things of the intellect and spirit'. ${ }^{71}$ As a matter of fact such encounters changed women's lives, beliefs and aspirations from a variety of angles and in different directions. Factory girls had the experience of 'a new world', since 'just being on the campus was very different in concept to what we from the factory were even aware of - only the rich knew that life', ${ }^{72}$ while faculty members had the opportunity to revise their political stances and views: 'The

\footnotetext{
${ }^{70}$ Bryn Mawr was very much influenced by the educational philosophy, vision and tutorial approach of the Workers' Educational Association in the UK as well as by other British models. Heller, 'Blue Collars and Blue Stockings', 111-12.

${ }^{71}$ Cited in Smith, Women Workers, 24.

${ }^{72}$ Freddy Drake Paine, class of 1934, in Heller, 'Blue Collars and Blue Stockings', 126.
} 
students were wonderful. They were overflowing with knowledge of a world I didn't know but felt I should have because my grandfather was a fisherman and my grandmother was a factory worker... The School turned my politics upside down. ${ }^{, 73}$

The Bryn Mawr School spanned two critical decades of the interwar period, while each of its students experienced two months of 'other spaces and other times' during their working year. The letter thus concludes with a reflection on temporal limitations: 'of course we cannot expect that every one gained equal knowledge for this short period', Pesotta notes, further acknowledging that the experience should be seen as a process rather than a finite outcome: 'this school is a start for those who know nothing, and training school for those who do know a little and need a thorough review of what they know'. The school is mapped here in the in-between spaces and times of women workers' lives and ultimately in the intermezzo of the troubling history of the twentieth century. But as already noted, it is always in the middle that crucial events erupt, new beginnings are made and glimpses of freedom emerge.

Such new beginnings in the middle always appear as discontinuous and fragmented events, but because they leave their traces in narratives they are not erased: their stories create archives of memory and political action through which the future can be glimpsed as open and radical. As Elizabeth Grosz has poetically suggested: 'what history gives us is the possibility of becoming untimely, of placing ourselves outside the constraints, the limitations and blinkers of the present'. ${ }^{74}$ In writing a letter in the middle of her experience at Bryn Mawr, Pesotta was actually imagining a future that the bleak reality of the 1920s could not recognise; she was thus contributing to the making of counter-histories by re-inscribing women workers in the cultural processes and formations of the twentieth century.

\section{Gendering the archives of the memory of work}

In this paper I have looked into grey areas in the archives of the memory of work by reading auto/biographical narratives of women workers in the garment industry. Pesotta's writings have constituted an exemplar that has illuminated gendered experiences in the memory of work, while her life story has configured a narrative assemblage within which multiple and horizontal connections have been made between archival documents, institutional histories and socio-political discourses and practices. What I have argued is that a genealogical approach to women workers' autobiographical narratives unveils significant gaps, silences and omissions in the cultural histories of the twentieth century, but also problematises and unsettles the writing of labour histories. Moreover these writings constitute archives of minor knowledges, counter-memories and radical futurities and open up new questions and perspectives in socio-historical studies of the memory of work that need to be further explored and theorised.

\section{Acknowledgments}

I want to thank the British Academy (SG112079) and the University of East London for funding my archival research at the New York Public Library Manuscripts and Archives Division. I am grateful to the NYPL Manuscripts and Archives Division for facilitating my research there and for giving me permission to cite from Rose Pesotta's and Fannia Cohn's

\footnotetext{
${ }^{73}$ Elizabeth Lyle Huberman, 1936 Faculty, in ibid.

${ }^{74}$ Grosz, The Nick of Time: Politics, Evolution and the Untimely (Durham, NC and London: Duke University Press, 2004), 17.
} 
papers. Special thanks to Tal Nadan for all her help and advice and to Elaine Leeder, for warmly responding to my request for help and advice on Rose Pesotta's papers.

\section{Notes on contributor}

Maria Tamboukou (BA, MA, PhD) is Professor of Feminist Studies and Co-editor of Gender and Education. Her research activity develops in the areas of critical feminisms, auto/biographical narratives and Foucauldian and Deleuzian analytics. Writing feminist genealogies is the central focus of her work. She is currently working with epistolary narratives on love and agonistic politics and on a genealogy of the seamstress, a British Academy funded project looking into auto/biographical narratives of home-based dressmakers and women working in the garment industry. 